\title{
PERSEPSI SISWA TERHADAP POSTER BERTEMA PERILAKU HIDUP SEHAT DAN BERSIH (PHBS) DI LINGKUNGAN SEKOLAH SMP TUNAS BARU JIN-SEUNG BATAM
}

\section{STUDENTS' PERCEPTIONS ABOUT POSTER OF HEALTHY AND CLEAN LIFE BEHAVIOUR AT SMP TUNAS BARU JIN SEUNG BATAM ENVIRONMENT}

\author{
Marina Sitorus $^{1}$, Notowinarto ${ }^{2}$, Destaria Sudirman ${ }^{3}$ \\ ${ }^{123}$ Program Studi Pendidikan Biologi, FKIP, Universitas Riau Kepulauan, Batam \\ *Korespondensi: notowinarto@gmail.com
}

\begin{abstract}
Abstrak
Penelitian ini untuk mengetahui "Persepsi siswa kelas VII terhadap poster yang bertema perilaku hidup bersih dan sehat di lingkungan sekolah SMP TUNAS BARU JIN-SEUNG Batam, dengan tujuan untuk mengetahui bagaimana persepsi siswa kelas VII terhadap poster bertema perilaku hidup bersih dan sehat (PHBS) di lingkungan sekolah. Waktu penelitian dilaksanakan pada bulan Juli-Agustus 2016. Menggunakan metode deskriptif dengan teknik pengumpulan data berupa angket. Teknik analisis data menggunakan uji validitas, reliabilitas, homogenitas, normalitas, dan uji F. Hasil validitas internal dan eksternal diperoleh 24 butir pernyataan yang layak digunakan dari jumlah 40 butir pernyataan, uji reliabilitas bersifat positip atau handal, sedangkan analisis nilai data angket bersifat terdistribusi normal dan homogen. Analisis diskriptif dari 80 siswa sebagai siswa eksperimen sebanyak 44 siswa (52.5\%) yang mempunyai persepsi baik terhadap poster, 30 siswa (40\%) yang mempunyai persepsi cukup baik, 6 siswa $(7,5 \%)$ yang mempunyai persepsi kurang baik dan tidak ada siswa yang mempunyai persepsi sangat tidak baik. Dengan demikian persepsi siswa kelas VII terhadap poster bertema PHBS di lingkungan sekolah SMP Tunas Baru Jin-Seung adalah baik. Jika dianalis dengan menggunakan Uji F persepsi bahwa poster tidak mempunyai pengaruh terhadap perilaku siswa (F hit < F tab).
\end{abstract}

\section{Kata Kunci: Media Pembelajaran, Persepsi, Poster, PHBS}

\begin{abstract}
This research is to find out "Students' perceptions about poster of healthy and clean life behaviour at SMP TUNAS BARU JIN-SEUNG BATAM environment, with the aim how class VII students' perceptions about poster of healthy and clean life behaviour at school environment. The research was conducted in JulyAugust 2016. It used descriptive method with questionnaire as the way to collect data. Data were analyzed by using test validity, reliability, homogeneity, normality, and $F$ count. Internal and external validity results obtained 24 worthy numbers from number of 40 statements. Reliability test was positive or reliable, while analysis questionnaire data value was distributed normally and homogeneous. Descriptive analysis of 88 experiment students, 44 experiment students (52.5\%) had good perception about poster, 30 experiment students $(40 \%)$ who had good enough perception, 6 experiment students $(7.5 \%)$ who had poor perception and no experiment student had very poor perception. Thus, class VII students' perception about posters of healthy and clean life behavior at SMP TUNAS BARU JIN-SEUNG BATAM environment was good. If it was analyzed by using $F$ test, the poster had no influence on student' behaviour $\left(F_{\text {hit }}<F_{\text {tab }}\right)$.
\end{abstract}

Keywords: Learning Media, Perception, Poster, Healthy and Clean Life Behaviour 


\section{PENDAHULUAN}

Dalam proses pembelajaran di lingkungan sekolah, kondisi yang bersih dan sehat sangat diperlukan agar proses kegiatan belajar-mengajar akan lebih mendorong siswa untuk semangat dalam mengikuti pembelajaran. Ada ungkapan menyebutkan bahwa kebersihan adalah sebagian dari iman yang berarti lingkungan yang bersih juga turut andil dalam menjadikan siswa lebih aktif, kreatif dan bertanggung jawab di lingkungan sekitar. Masalah yang sering ditemukan dalam lingkungan sekolah adalah kurangnya kesadaran atau sikap ketidakpedulian siswa terhadap kebersihan lingkungan. Kebiasaan siswa membuang sampah tidak pada tempatnya, mengakibat sampah ditemukan dimana-mana seperti di teras kelas, di halaman sekolah, di lapangan olah raga atau banyak dijumpai pada parit air buangan. Hasil pengamatan terindikasi adalah akibat kurangnya kesadaran siswa akan kondisi lingkungan yang kurang bersih dan sehat serta rendahnya dalam memelihara kebersihan lingkungan sekolah. Hal lain adalah belum adanya poster yang menggambarkan tahapan anjuran atau arahan sikap dan tindakan siswa yang harus dilakukan di rumah ataupun di sekolah, bertema perilaku hidup bersih dan sehat (PHBS). Penelitian ini bertujuan untuk mengetahui bagaimana persepsi siswa kelas VII terhadap poster bertema perilaku hidup bersih dan sehat (PHBS) di lingkungan sekolah SMP TUNAS BARU JINSEUNG Batam TA 2015/2016.

\section{METODOLOGI}

Penelitian dilakukan di SMP Tunas Baru Jin-Seung yang beralamat di jalan Batu Aji, Kavling Batu Aji Baru Blok B 12 No. 3. Kota Batam. Penelitian ini dilaksanakan pada bulan Juli - Agustus 2016. Jenis penelitian deskriptif dengan materi poster yang bertema perilaku hidup bersih dan sehat (PHBS) di lingkungan sekolah. Populasi dalam penelitian ini adalah semua siswa kelas VII SMP Tunas Baru Jin-Seung Batam yang berjumlah 115 siswa dalam 3 kelas (kelas A 35 siswa, kelas B 40 siswa dan kelas C 40 siswa). Penggunaan media gambar berupa poster berukuran Kuarto $(21 \mathrm{~cm}$ x $27 \mathrm{~cm})$ yang merupakan variabel dalam penelitian ini, penilaian menggunakan skala Linkert yakni dengan 5 (lima) pilihan jawaban: sangat setuju (SS nilai 5); setuju (S nilai 4), tidak setuju (TS nilai 3); kurang setuju (KS nilai 2) dan sangat tidak setuju (STS nilai 1). Teknik sampling yang digunakan dalam penelitian ini adalah Teknik Purposive Sampling (Arikunto. 2012). Kisi-kisi instrumen persepsi siswa PHBS di sekolah sebagai berikut; 
Tabel 1. Kisi-kisi Persepsi Siswa Terhadap Poster PHBS

\begin{tabular}{ll}
\hline \multicolumn{1}{c}{ Indikator } & \multicolumn{1}{c}{ Nomor Butir } \\
\hline 1. Kebiasaaan sebelum berangkat ke sekolah & $1,2,3,4,5,6,7$ \\
2. Hal-hal yang dilarang di lingkungan sekolah & $10,11,12,13,14,15,16,17,18$, \\
& 19 \\
$\begin{array}{l}\text { 3. Kebersihan jamban dan lingkungan harus dijaga } \\
\text { untuk menghindari jentik nyamuk. }\end{array}$ & $20,21,22,23,24,25$ \\
4. Setelah mengkonsumsi jajanan sehat di kantin & $26,27,28,29,30,31,32,33$, \\
$\quad$ sekolah harus membuang sampah pada & $34,3536,37,38$ \\
$\quad$ tempatnya dan mencuci tangan dengan air bersih. & \\
5. Kebiasaan berolahraga akan mempengaruhi berat & 39,40 \\
$\quad$ dan tinggi badan siswa. &
\end{tabular}

Analisis uji instrumen yaitu uji coba instrumen internal/rasional yaitu dengan Dosen UNRIKA Pendidikan Biologi sebanyak 3 orang, sedangkan uji coba instrumen eksternal diberikan kepada siswa kelas VII A 35 siswa dan uji utama kelas VII B dan VII $\mathrm{C}$ sebanyak 80 siswa. Hasil instrumen diberi skor dan dianalisis secara berurutan yaitu; a) Uji Validasi instrumen dalam penelitian ini menggunakan validasi butir soal yakni dengan mengkorelasikan seluruh skor faktor dari skor butir soal dan menghitung korelasi Product Moment antara butir dengan faktor (Sutrisno Hadi, 1991 dalam Erlinawati, 2013); b) Uji Reliabilitas angket dilakukan dengan perhitungan koefisien reliabilitas mengunakan teknik Alpha Cronbach dengan tujuan setiap butir soal yang disusun memiliki keterandalan secara empirik (Sugiyono. 2015).

Data dari hasil uji utama selanjutnya diolah dengan cara deskriptif dan disajikan dalam tabel Prasyarat Analisis Diskriptif meliputi: jumlah sampel, jumlah total data, data maksimum, data minimum, rentang, mean, median, modus, standar deviasi, varians serta distribusi frekuensi. Tabel distribusi frekuensi dan grafik histogram interval nilai hasil persepsi poster.

Kemudian dilakukan Uji Prasyarat Data meliputi; Uji Normalitas Data, untuk menggambarkan sebaran data hasil penelitian berdistribusi normal atau tidak. Menggunakan Uji Kolmogorov-Smirnov; Uji Homogenitas untuk mengetahui apakah data bersifat homogen/seragam atau tidak dengan pendekatan pengujian bilangan levene statistic; serta Uji $\mathrm{F}_{\text {hit }}$ Persepsi dengan formula nilai varians terbesar dibagi varians terkecil kemudian nilai $\mathrm{F}_{\text {hit }}$ tersebut dibandingkan dengan nilai $\mathrm{F}_{\text {tabel } \alpha=5 \%} ;$ bila $\mathrm{F}_{\text {hit }}>\mathrm{F}_{\text {tab }}=$ maka persepsi tema poster dapat diterima dan sebaliknya bila $\mathrm{F}_{\text {hit }}>\mathrm{F}_{\mathrm{tab}}=$ tidak dapat diterima (Furchan, 2007). 


\section{HASIL DAN PEMBAHASAN}

Data uji instrumen meliputi: uji Validitas, hasil terdiri uji validitas eksternal/empiris butir instrumen penelitian kepada 35 siswa kelas VII di SMP Tunas Baru Jin-Seung, diperoleh dari 40 butir pernyataan yang diujicobakan, kemudian dianalisis maka diperoleh hasil $r_{\text {hit }}>r_{\text {tab }}$ sebanyak 24 butir pernyataan dinyatakan valid serta 16 butir pernyataan dinyatakan tidak valid atau drop atau $\mathrm{r}_{\text {hit }}<\mathrm{r}_{\text {tab }}$ (Tabel 2), sedangkan uji Reliabilitas instrumen butir angket dilakukan dengan perhitungan Alpha Cronbach, dari total 40 butir instrumen sebanyak 24 dinyatakan reliabel atau handal diperoleh nilai $\mathrm{r}_{11 \text {.hit }}$ $0.868>\mathrm{r}_{11 . \text { tab }} 0.722$ (Tabel 3).

Tabel 2. Hasil Rekapitulasi Uji Validitas Setiap Butir Pernyataan Angket Persepsi Siswa Kelas VII terhadap Poster Bertema PHBS di Sekolah

\begin{tabular}{|c|c|c|c|c|c|}
\hline $\begin{array}{c}\text { Jumlah } \\
\text { Butir }\end{array}$ & $\begin{array}{c}\text { Jumlah } \\
\text { Butir } \\
\text { Valid }\end{array}$ & $\begin{array}{l}\text { No. Butir } \\
\text { Valid }\end{array}$ & $\begin{array}{c}\text { Jumlah } \\
\text { Butir Drop }\end{array}$ & $\begin{array}{l}\text { No. Butir } \\
\text { Drop }\end{array}$ & $\begin{array}{c}\mathbf{r} \\
\text { Tabel }\end{array}$ \\
\hline 40 & 24 & $\begin{array}{c}2,4,6,10,14,1 \\
9,21,22,23,2 \\
5,26,28,29,3 \\
0,31,32,33,3 \\
4,35,36,37,3 \\
8,39,40\end{array}$ & 16 & $\begin{array}{c}1,3,5,7,8,9, \\
11,12,13,1 \\
5,16,17,18, \\
20,21,24,2 \\
7,28\end{array}$ & 0,334 \\
\hline
\end{tabular}

Tabel 3. Rekapitulasi Hasil Uji Reliabilitas Instrumen Angket Persepsi Siswa Kelas VII terhadap Poster Bertema PHBS di Sekolah

\begin{tabular}{cc}
\hline Cronbach's Alpha & No. of Items \\
\hline $\mathbf{8 6 8}$ & $\mathbf{2 4}$ \\
\hline
\end{tabular}

Tabel 4. Rekapitulasi Hasil Perhitungan Statistik Deskriptif Nilai Persepsi Siswa Kelas VII Terhadap Poster Bertema PHBS di Sekolah

\begin{tabular}{clc}
\hline No & \multicolumn{1}{c}{ Statistik Diskriptif } & $\begin{array}{c}\text { Nilai Persepsi Siswa Kelas VII } \\
\text { Terhadap Poster }\end{array}$ \\
\hline 1 & Jumlah Sampel (n) & 80 \\
2 & Jumlah Total Data $(\Sigma)$ & 7012 \\
3 & Data Maksimum (Max) & 102 \\
4 & Data Minimum (Min) & 62 \\
5 & Rentang (r) & 40 \\
6 & Rerata (Mean) & 87.65 \\
7 & Modus (Mo) & 99 \\
8 & Median (Me) & 89.5 \\
9 & Simpangan Baku (S) & 10.37 \\
10 & Varian $\left(S^{2}\right)$ & 107.54 \\
\hline
\end{tabular}


Data hasil penelitian utama yang diambil secara teknik purposive sampling pada kelas VII B dan VII C dengan total jumlah sebanyak 80 siswa. Data diolah secara deskripsi dan disajikan dalam tabel distribusi frekuensi dan grafik histogram berupa gambaran umum sebagai berikut jumlah sampel, jumlah total data, data maksimum, data minimum, rentang, mean, median, modus, standar deviasi, varians serta distribusi frekuensi (Tabel 4 dan 5 dan Gambar 1).

Tabel 5. Distribusi Frekuensi Nilai Persepsi Siswa Kelas VII Terhadap Poster

\begin{tabular}{|c|c|c|c|c|c|}
\hline \multirow[b]{2}{*}{ No } & \multirow[b]{2}{*}{ Kelas Interval } & \multicolumn{2}{|c|}{ Batas Kelas } & \multicolumn{2}{|c|}{ Frekwensi } \\
\hline & & Batas Bawah & $\begin{array}{c}\text { Batas } \\
\text { Atas }\end{array}$ & $\begin{array}{l}\text { Absolut } \\
\text { (Siswa) }\end{array}$ & $\begin{array}{c}\text { Relatif } \\
(\%)\end{array}$ \\
\hline 1 & $62-67$ & 61.5 & 67.5 & 4 & 5.00 \\
\hline 2 & $68-73$ & 67.5 & 73.5 & 2 & 2.50 \\
\hline 3 & $74-79$ & 73.5 & 79.5 & 12 & 15.00 \\
\hline 4 & $80-85$ & 79.5 & 85.5 & 10 & 12.50 \\
\hline 5 & $86-91$ & 85.5 & 91.5 & 18 & 22.50 \\
\hline 6 & $92-97$ & 91.5 & 97.5 & 18 & 22.50 \\
\hline 7 & $98-103$ & 97.5 & 103.5 & 16 & 20.00 \\
\hline \multicolumn{3}{|c|}{ Jumlah } & 80 & \multicolumn{2}{|c|}{100.00} \\
\hline
\end{tabular}

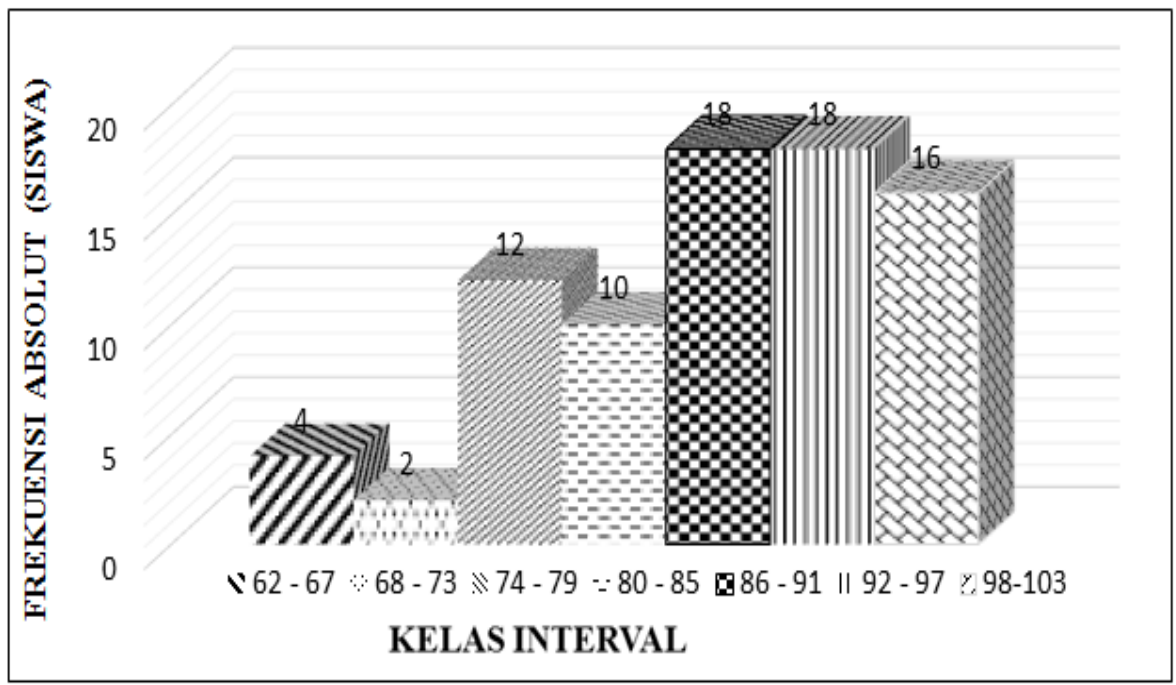

Gambar 1. Nilai Persepsi Siswa Kelas VII Terhadap Poster

Berdasarkan nilai standarisasi persepsi poster (Erlinawati, 2013) disimpulkan dari 80 siswa, sebanyak 44 siswa atau 52.5\% yang memiliki sikap baik terhadap lingkungan sekolah, sebanyak 30 siswa atau 40\% yang memiliki sikap cukup baik, dan sebanyak 6 siswa atau $7.5 \%$ yang memiliki sikap kurang baik. Hasil diatas sangat didominasi oleh siswa yang cukup mengerti permasalahan kebersihan dan kesehatan di lingkungan sekolah. 
Hasil pengujian prasyarat data meliputi: a) Uji normalitas data; menggunakan pendekatan uji Kolmogorov-Smirnov menunjukkan nilai Kolmogorov-Smirnov sebesar 0.874 dan nilai Asymp.Sig sebesar 0.430 sehingga disimpulkan bahwa nilai normalitas bilangan Kolmogorov Smirnov (0.874) > nilai Asymp.Sig (0.430), berarti data berdistribusi normal. Dapat diinterpretasikan bahwa sebaran data yang diperoleh berasal dari populasi yang sama yaitu kelas VII dengan kemungkinan ada keseragaman pengetahuan terhadap lingkungan sekolah (Tabel 6); b) Uji homogenitas untuk menguji apakah data bersifat homogen/seragam atau tidak. Dari hasil analisis bilangan levene statistic $=1.949$ sedangkan nilai Signifikan $=0.117$, menunjukkan bahwa nilai levene statistic $(1.949)>$ Sig (0.117), maka dapat dinyatakan bahwa data mempunyai varian yang homogen atau berasal dari populasi yang seragam (Tabel 7); dan c) Uji $F_{\text {hit }}$ Persepsi untuk mengetahui secara empiris apakah tema dan bobot materi poster sebagai media atau sarana publikasi penambahan pengetahuan tentang lingkungan PHBS dapat diterima secara kognitif oleh para siswa. Hasil olah data menunjukkan bahwa nilai $F_{\text {hitung }}=1.60$ sedangkan $F_{\text {tabel }}(\alpha=$ $5 \%)=1.980$. Dengan demikian $\mathrm{F}_{\text {hit }}<\mathrm{F}_{\text {tab }}$, dinyatakan tidak nyata atau non-signifikan (NS), sehingga dapat dinyatakan bahwa format dan konten materi poster ternyata belum memberikan informasi yang cukup tentang PHBS, berakibat tidak mempunyai pengaruh nyata terhadap sikap dan perilaku siswa secara umum pada sekolah tersebut terhadap lingkungan sekitar sekolah mereka.

Tabel 6. Rekapitulasi Hasil Uji Normalitas (Kolmogorov-Smirnov Test)

\begin{tabular}{llc}
\hline \multicolumn{1}{c}{ Parameter } & Nilai Persepsi Siswa Kelas VII \\
\hline $\mathrm{N}$ & & 80 \\
Normal & Mean & 87.6500 \\
Parameters $^{\mathrm{a}, \mathrm{b}}$ & Std. Deviation & 10.43797 \\
& Absolute & .138 \\
Most Extreme & Positive & .113 \\
Differences & Negative & -.138 \\
\multicolumn{2}{l}{ Kolmogorov-Smirnov Z } & .874 \\
Asymp. Sig. (2-tailed) & .430 \\
\hline
\end{tabular}

Tabel 7. Hasil Perhitungan Homogenitas Data

\begin{tabular}{ccc}
\hline Levene Statistic & df1 & Sig. \\
\hline 1.949 & 6 & .117 \\
\hline
\end{tabular}


Berdasarkan pengujian secara diskriptif menunjukkan bahwa media poster perilaku hidup bersih dan sehat (PHBS) memberikan persepsi yang sangat dari pendapat siswa kelas VII di sekolah SMP Tunas Baru Jin-Seung. Bila berdasarkan klasifikasi nilai baik dan cukup baik, jumlahnya mencapai angka sebesar 92,5\% sisanya menganggap poster tersebut tidak baik atau tidak representatif. Tanggapan tersebut sangat mungkin terjadi karena performance poster itu unik dan mempunyai daya tarik tertentu. Pada prinsipnya media yang kreatif dalam proses pembelajaran akan mendatangkan solusi cerdas, yakni dapat meningkatkan nilai kesadaran dan partisipasi siswa terhadap kondisi lingkungan melalui mediasi salah satunya adalah poster. Karenanya seorang guru wajib berusaha untuk selalu kreatif menciptakan media pembelajaran atau alat peraga yang sesuai dan menarik minat siswa (Arsyad, 2015).

Hasil penelitian yang dilakukan oleh Erlinawati (2013) menunjukkan bahwa persepsi siswa kelas VIII terhadap Media Gambar dalam Pembelajaran Bola Basket adalah cukup baik. Secara rinci, dari total siswa yang diuji sebanyak 118 siswa, persepsi siswa yang positif sebesar 45 siswa $(38,14 \%)$ mempunyai persepsi cukup positif serta mendorong lebih giatnya untuk bermain bola basket dikalangan siswa. Jika ilihat dari nilai persepsi siswa terhadap poster bertema PHBS maka seharusnya lingkungan sekolah akan semakin bersih, sehat dan nyaman, sehingga menjadikan proses pembelajaran dapat berjalan dengan lancar. Serta diharapkan tingkat kehadiran dan tindakan siswa dalam menerapkan PHBS di sekolah lebih meningkat untuk diri siswa sendiri dan untuk lingkungan sekitar.

Berdasarkan hasil analisis diskriptif yakni; nilai rata-rata 87,65 dan median 89,5 dengan modus nilai 99. Hasil ini menunjukkan bahwa tanggapan siswa terhadap poster ternyata dapat dengan cepat memahami materi yang tercakup didalamnya. Menurut Suparman (1997) dalam Arsyad (2015) mengemukakan manfaat media pembelajaran dalam proses belajar siswa, yaitu pembelajaran akan lebih menarik perhatian siswa sehingga dapat menumbuhkan motivasi belajar dan bahan pembelajaran akan lebih jelas maknanya sehingga lebih dapat dipahami oleh siswa dan memungkinkannya menguasai dan mencapai tujuan pembelajaran.

Sedangkan pada analisis persepsi terhadap bobot poster menggunakan pendekatan uji $\mathrm{F}$ persepsi ternyata didapatkan bahwa pada tataran data yang diperoleh, poster tersebut tidak memberikan nilai nyata atau non-signifikan $(n=79$ dan nilai kepercayaan $\alpha=5 \%)$, dalam angka perhitungan $F_{\text {hit }} 1,60<\mathrm{F}_{\text {tab }}$ 1,98. Sehingga dapat dikatagorikan bahwa sebenarnya bobot poster tersebut tidak mempengaruhi cara menilai dari siswa atau dapat dikatakan bahwa rangkaian konten poster dianggap hal yang biasa dilakukan sehari-hari 
dan tidaklah efektif.

Berdasarkan uraian di atas bahwa penggunaan media gambar sebagai alat bantu visual dalam proses komunikasi pendidikan adalah satu hal yang tidak boleh dihiraukan, bahwa tidak semua persepsi atau pemahaman siswa terhadap suatu media/gambar itu sama. Sehingga dalam hal ini peranan guru sangat penting guna untuk menyaman perbedaan persepsi siswa tersebut. Dapat disimpulkan bahwa persepsi siswa kelas VII terhadap poster yang bertema PHBS baik. Hal tersebut dibuktikan dari banyaknya siswa yang mempunyai persepsi baik terhadap poster yang diberikan dan didukung oleh beberapa penelitian yang relevan.

\section{KESIMPULAN}

Berdasarkan hasil penelitian dapat ditarik kesimpulan bahwa persepsi siswa kelas VII terhadap poster bertema PHBS di lingkungan sekolah SMP Tunas Baru Jin Seung adalah baik. bahwa dari 80 siswa responden sebanyak $92.5 \%$ yang memiliki sikap baik terhadap lingkungan, Uji $\mathrm{F}$ persepsi menunjukkan bahwa poster tidak mempunyai pengaruh nyata $(\mathrm{F}$ hit $<\mathrm{F}$ tab).

\section{REFERENSI}

Arikunto, S. 2012. Prosedur Penelitian Suatu Pendekatan Praktik. Jakarta: Rineka Cipta.

Arsyad, A. 2015. Media Pembelajaran. Jakarta: Grafindo Persada.

Erlinawati Nur. 2013. Persepsi Siswa Kelas VIII Terhadap Media Gambar Dalam Pembelajaran Bola Basket Di SMP N 2 Bambanglipuro. Skripsi: Program Studi: Pendidikan Jasmani Kesehatan dan Rekreasi. Fakultas Ilmu Keolahragaan Universitas Negeri Yogyakarta.

Furchan, E. 2007. Pengantar Penelitian Dalam Pendidikan. Malang: Pustaka Pelajar,

Sugiyono. 2015. Metode Penelitian Pendidikan Pendekatan Kuantitatif, Kualitatif dan $R \& D$. Bandung: Alfa Beta. 